Gill, D.L. (2001). Feminist sport psychology: A guide for our journey. The Sport Psychologist, 15, 363-372.

The Sport Psychologist, 2001, 15. 363-372

(c) 2001 Human Kinetics Publisbers. Inc.

\title{
Feminist Sport Psychology: A Guide for Our Journey
}

\author{
Diane L. Gill \\ University of North Carolina at Greensboro
}

\begin{abstract}
Feminist spon psychology encompasses many approaches and has many variations. The articles in uhis special issue reflect that variation but also reflect conmon themes outlined in this introductory article. The feminist framework for this article begins wich bell hooks' (2000) inclusive, action-oriented definition of feminism as "a movement to end sexism, sexist exploitation, and oppression" (p. viii). The following themes, drawn from ferwinist theory and sport studies scholarship, provide the supporting structure: (a) gender is relational rather than categorical; (b) gender is inextricably linked with race/ etbricity, class, and other social identities; (c) gender and cultural relations involve power and privilege: and (d) feminism demands action. Gender scholarship in sport psychology is reviewed noting recent moves toward feminist approaches and promising directions that incorporate cultural diversity and relational analyses to move toward feminist practice. The other articles in this issue reflect similar feminist themes and present unique contributions to guide us toward feminist sport psychology.
\end{abstract}

This special issue of The Sport Psychologist (TSP) is based on a symposium presented at the Association for the Advancement of Applied Sport Psychology (AAASP) conference in 2000 . In that symposium, organized by Vikki Krane, the authors of the lead papers in this issue came together to share their views on the past, present, and future of feminist spoit psychology. All of the authors were eager to contribute to this effort. Sport psychologists concemed about gender issues in their research and practice find limited research and few resources. Moreover, the sport psychology literature lacks guiding frameworks and provides few opportunities to engage in dialogue that might help us develop our own guiding feminist perspectives. Preparing this issue gave us an opportunify to share views and further develop our own feminist perspectives. We hope that by presenting this collaborative work, more sport psychologists will join in as we continue our feminist sport psychology journey.

The author is with the Dept. of Exercise and Sport Science, University of North Carolina at Greensboro, NC 27402-6169. E-mail: <diane_gill@uncg.edu>. 
In this introductory article. I will provide a guide to our feminist sport psychology journey. After presenting a general definition and overview of feminist perspectives in sport psychology, I will provide a brief overview of papers noting some themes and connections. Astute readers recognize that we do nol have one feminist sport psychology, but many. I cannot adequately cover the other authors' views-you must read all the articles. The variations and differing perspectives are the strength of feminist sport psychology. Each author contributes her own insighrs and interpretations. You will find considerable overlap and common themes. but you will also find some unique contributions in each paper. As you read and reflect, you may accept some views, reject others, modify and incorporate some views, and develop your unique perspective.

\section{Feminism}

As we go in search of feminist sport psychology, we nught clarify some termis and frameworks. In particular, the term "feminist" carries many meanings, and we have no single feminist perspective shared by all those who accept the label. As most readers realize, feminist approaches typically emphasize subjective interpretations and reject the illusion of objective reality. Femirist sport psychology, as presented here, reflects my interpretarions. The other authors in this issue may well offer differing interpretations, and readers are invited and encouraged to do as well.

Feminism, the "F" word in many circles, is not easily defined by those who claim to be feminist. Note that those who claim not to be feminist often have clear definitions, but that doesn't help those of us struggling to develop our frameworks. Few texts or articles found on women's studies reading lists offer such definitions. Students and professionals often stumble over words or respond defensively when asked for a definition.

I find the definition from bell hooks' 1984 book, Feminist Theory: From Margin to Center. most helpful to students and useful as a guide. In chapter 2, titled, "Feminism: A movement to end sexist oppression," hooks discusses issues related to definitions. As hooks notes in her more recent (2000) book. Feminism is for Everybody, that definition holds up well. In the introduction (hooks, 2000), she invites everybody to read and understand that "Feminism is a movement to end sexisn, sexist exploitation, and oppression" (p. viii).

The definition is inclusive rather than exclusive and focused on action to end oppression. Clearly, men have the power in a sexist system, but men are also restricted by sexism, and men can be part of the movement. hooks has written extensively, in very accessible language, on feminist theory, and she has always emphasized the need to incorporate race and class into a true feminist perspective. I find hooks' inclusive, action-oriented detiojtion both elegant and useful. The feminist perspectives that 1 find most helpful for sport psychology share those characteristics.

\section{Feminist Sport Studies}

Sport psychology does not have well-developed feminist theories or models. Most of the authors in this issue, and others who have taken feminist perspectives, have 
looked to other areas for their feminist guides. Much of the women's studies scholarship and discussions of feminist theory are in the humanities. hooks is a writer and cultural critic, as well as a feminist theorist. That work clearly informs ferwinist scholars in social and behavioral sciences, but "hard" science and medical models dominate and present challenges. Psychology has only begun to adopt true feminist approaches, and sport psychology lags further behind.

Clearly, gender issues are prominent in sport psychology, and a feminist perspective (or perspectives) could belp us address these many issues. Sport psychology typically follows the lead of the larger psychology area, and some current psychologists are beginning to take more feminist approaches. We can look to those psychologists, as well as to the women's studies scholars, as we are developing our feminist perspectives. Those of us with stronger ties to exercise and sport science also have the work of some clearly feminist sport studies scbolars as a guide. Indeed, feminist sport studies scholars have been my inspiration from the beginning of my own feminist sport psychology journey.

M. Ann Hall's (1996) book, Feminism and Sporting Bodies, subtitled, "Essays on theory and practice." is my recommended guide for any sport psychologist on a feminist journey. Hall, who recently retired from the University of Alberta, has been a leading sport studies scholar and clear voice for feminism throughout her career. Hall's stated purpose is to "speak feminism" and to explain feminist theory in relation to sport. The 1996 book begins by tracing her "30-year intellectual odyssey in the struggle to understand and apply feminist theory" (p. vi). The subsequent chapters move the reader from the earlier feminist models to feminist cultural studies and a gender relations perspective.

Hall focuses on theory, but her presentation is clear and concise. Even sport psychology scholars will recognize the limits of our biologic and categorical models and the need to take a relational perspective. Gender relations acknowledges the pervasive, dynamic role of gender in all our interactions and behaviors. Moreover, cultural studies incorporates multiple power relations. That is, gender relations involve power; males have a more doninant, privileged status in gender relations. Note that this reflects sexist oppression in hooks' definition. Also, cultural studies clearly incorporates race, class, and other power relations that operate in society and interact with gender in varying, complex ways. Hall's final chapters move from theory into action, in true feminist fashion, as she discusses feminist research as praxis (moving from our theories to real world action) and socialpolitical action.

Ann Hall clearly "speaks feminism" to me. Indeed, Ann Hall was the first person who spoke feminism to me, and her work has always helped me find feminist direction in sport psychology. Ann visited the University of Waterloo in the late 1970 s where I was a beginning faculty member applying social psychology theory in experimental research in a male-dominated and science-oriented program. Ann's presentation brought a spark of feminist light to my world, and I have continued to look to the sport studies scholars in finding my feminist directions. Nancy Theberge, my faculty colleague at Waterloo, and Susan Birrell, my colleague at Iowa, are leading feminist sport studies scholars who continue to offer new insights, challeuge sport psychology perspectives, and guide us on our feminist sport psychology joumey. I encourage all sport psychologists to look at the sport studies scholarship. By considering alternatives and challenges, we clarify our perspectives and move ahead in our own directions. 
Listed below (psychologists like lists) are the key themes from the feminist theory and sport studies scholarship that guide my feminist sport psychology journey. The psychologists who are beginning to take ferninist perspectives share many of these views, and you will find similar themes in the other articles in this issue:

- Gender is relational, not categorical. Gender influences everyone, and gender relations are complex and dyaamic. Research and theory that assumes simple, dichotomous categories cannot explain real world behavior.

- Gender is inextricably intertwined with race/ethnicity, sexuality, social class, and other cultural identities. We all have multiple, intersecting identities. It is probably impossible to sort out how much any one aspect of our identity (e.g., gender, race) influences any given behavior.

- Gender and cultural relations involve power. Power, privilege, and oppression are relational and dynamic. Most people are both in positions of privilege and targets of oppression. The salience of our varying identities and power relations vary with time and context.

- Feminist theory must move to action. Feminism demands action to end oppression through our professional work and political/social action.

These themes are evident in the growing feminist psychology work, although psychology is still dominated by hard science models, and leminists face resistance. I am particularly encouraged by the current feminist psychology work that promotes social perspectives and calls to action. The themes parallel the feminist sport studies approaches, and sport psychologists can look to feminist scholarship across areas as we develop a feminist sport psychology. Clearly, our existing sport psychology scholarship has not taken a feminist path. We have addressed gender issues, and we have no lack of issues that could benefit from feminist approaches. The next section covers, briefly (see Gill, in press for extended discussion), gender scholarship in sport psychology. As the review suggests, we have not been guided by feminist theory. I hope the review will also suggest that by continuing to debate feminist perspectives and develop feminist sport psychology, we can better address these gender issues and also move in new direcrions to eorich our sport psychology research and practice.

\section{Gender Scholarship in Sport Psychology}

Despite the pervasiveness and power of gender in sport, and the infinite number of psychological questions we could ask, sport psychology research on gender is limited in all ways. Our theories and frameworks are even more limited and hardly feminist. Our research questions and methods focus on differences and neglect complex gender issues and relations, and we lack guiding conceptual frameworks to help us understand the complexities of gender in sport and exercise contexts. In some ways, spor psychology reflects the larger discipline of psychology, which has been slow to move beyond isolated studies of sex differences to more complex issues of gender relations. In other ways, our neglect of gender reflects the place of women in sport and in sport psychology.

By definition, psychology focuses on individual behavior, thoughts, and feelings. But we cannot fully understand the individual without considering the larger world. Trickett. Watts, and Birman (1994) note that diversity has challenged the foundations of psychology by suggesting that traditional psychology is 
particularistic rather than universal and that its theories reflect views, limits, and social contexts of those who created them. They further suggest that psychology's biggest challenge is paradigmatic. We need new ways of thinking to understand diversity. They advocate moving from the dominant psychology view, which emphasizes biology, isolating basic processes, rigorous experimental designs, and a critical-realist philosophy of science, to an emphasis on people in contexı.

Adopting a feminist perspective in sport psychology fits with Trickett et al.'s (1994) framework. Sport psychology is explicitly context dependent, and the context encompasses diverse participants in all forms of physical activities in varied exercise and sport settings. Gender makes a difference, and we must consider people in context to understand their behavior. Biological sex is related to gender, but biology does not explain gendered sport. All the meanings, social roles, expectations, standards of appropriate behavior, beauty, power, and status are constructed in the sport culture. We are not born to wear high heels or high-top sneakers, but from the time we are boru, our world is shaped by gender. Our parents, teachers, peers, and coaches react to us as girls or boys. Gender is such a pervasive influence in society that it is impossible to pinpoint. Sport is no exception, but the sport world does have unique characteristics.

\section{The Social Context of Gender and Sport}

To move toward feminist sport psychology, we must first understand the social and historical context. Both psychology and physical education have their beginnings in the late $1800 \mathrm{~s}$. We can find women and gender issues in both histories, but the histories are quite different. In psychology, we find women pioneers facing discriminatory practices and attitudes but persisting to make a place in the academic discipline of psychology, much as women have made a place in many scholarly fields. In physical education, we find a legacy of strong women leaders who developed women's physical education as an alternative, separate from men's physical education programs. Gender issues in sport and exercise psychology today bave roots in women's physical education and some parallels in psychology, but we have few direct ties and must do some searching to find those roots.

Along the psychology roots, I look to Carolyn Sherif as the psychologist who most moved us toward feminist sport psychology. Sherif often contributed to sport psychology conferences and scholarship, and she challenged our thinking about many issues including competition, group processes, and gender. Sherif posed an early, persuasive feminist challenge that helped tum psychology loward a more social and woman-oriented perspective. Sherif (1982) likened the term "sex roles," which dominated sport psychology as well as psychology gender research, to a "boxcar carrying an assortment of sociological and psychological data along with an explosive mixture of myth and untested assumptions" (p. 392). Sherif's early and persistent advocacy of social psychology, which helped psychologists advance gender scholarship, has had considerable influence on my work as it has on several others in sport psychology.

Just as women had a place in the beginnings of psychology, women bad a place in the early days of physical education. Indeed, women had a highly visible presence. Women's physical education provided a women-oriented environment long before the women's movement of the 1970 s began to encourage such programs.

One aspect of early women's physical education that seems at odds with loday's sport psychology is the approach to competition and athletics. At a 1.923 
conterence, which is a benchmark for this anti-competition movement, key physical education leaders set guidelines that included putting athletes first, preventing exploitation, downplaying competition while emphasizing enjoyment and sportsmanship, promoting activity for all rather than an elite few, and utilizing women as leaders for girls and women's sports. A related clarifying statement (NAAF, 1930) concluded with the classic, "A game for every girl and every girl in a game."

The sentiments of the 1923 conference dominated women's plasical education and sports programs through the social movements of the $1960 \mathrm{~s}$ and $1970 \mathrm{~s}$ and the 1972 passage of Title IX of the Educational Amendments Act. Discrimination persists and Title IX challenges continue today, but women and girls have taken giant steps into the competitive sport world. In the U.S., women now constitute about one-third of the high school, college, and Olympic athletes in the United States. But, one-third is not one-half, and in other ways, women have lost a place. Sport remains male-dominated with a clear hierarchical structure that is widely accepted and communicated in so many ways that we seldom notice.

\section{Gender Scholarship in Psychology}

Gender scholarship in sport and exercise psychology follows gender scholarship within psychology. That scholarship has progressed from sex differences (males and females are opposites), to an emphasis on gender role as personality (males = females, if treated alike), to more current social psychology models that emphasize social context and processes. As Basow and Rubin (1999) explain in their chapter on gender influences in adolescence, gender refers to the meaning attached to being female or male in a particular culture. and gender role expectations also vary with ethnicity, social class, and sexual orientation.

\section{Gender Relations and Cultural Diversity- Promising Directions}

Feminist and cultural studies perspectives call for consideration of gender within the wider context of cultural diversity. Sport is not only male, but white, young, middle-class, heterosexual male. And gender affects men as well as women in sport. Michael Messner, a sport studies scholar who gave a wonderful keynote address at the 1999 AAASP conference, describes sport as a powerful force that socializes boys and men into a restricted masculine identity. Messner (1992) cites the major forces in sport as (a) competitive hierarchical structure with conditional self-worth that enforces the "must win" style, and (b) homophobia. Like Hall and other feminist sport studies scholars. Messner emphasizes the social context and relational analyses as he describes the intersecting influences of gender and homophobia on sport behavior.

Sport psychology has progressed from the limited sex differences and gender role approaches, but we have not incorporated diversity or adopted relational analyses that might help us develop a useful feminist sport psychology. As Hall (1.996) notes, sport psychologists have relied on categorical research to study gender. We focus on differences, whether we rely on biological or socialization explanations. We focus on individuals and fail to analyze the powerful ways in which gender and race relations are socially and historically constructed. Yevonne Smith (1992), in her review of the research (or lack of) on women of color, called for ". . . more relational analyses of and by diverse women of color and to understand how 
collective personal experiences and processes are informed by race, gender, and class power relations" (p. 224). To move toward feminist sport psychology, we must heed the call of the sport studies scholars and consider the many intersections of gender, race, class, and other power relations.

Gender is part of a complex, dynamic, ever-changing social context and a particularly salient. powerful part within sport and exercise settings. Feminist perspectives and relational analyses will enrich our sport psychology scholarship. Moreover, consideration of gender relations and recognition of diversity is critical to effective sport psychology practice.

\section{Toward Feminist Sport Psychology Practice}

Moving from feminist theory to feninist sport psychology practice is a challenge, to grossly understate the obvious. But the expanding literature on feminist practice in psychology provides some guidance. To move toward feminist practice, we must furst avoid sexist assumptions, standards, and practices. Then, we might follow the lead of psychologists who have moved to more proactive feminist approaches. Feminist practice (Worell \& Remer, 1992) incorporates gender scholarship, emphasizes neglected womeo's experiences (e.g. sexual harassment), and takes a more nonbierarchical, empowering. process-oriented approach that shifts emphasis from personal change to social change.

Recently, calls for feminist practice have been broadened to include all areas of research, education., and practice in psychology. In July 1993 a National Conference on Education and Training in Feminist Practice was held to create an agenda for feminist practice. In the preface to the collective conference report, Worell and Johnson (1997) note that feminist practice is widely defined to include activities related to all areas of psychology-research, teaching, clinical practice and supervision, scholarly writing, leadership, and any other activities in which psychologists participate. The collection includes summaries and consensus statements on feminist practice and directions for specific practice areas, as well as themes that cross all areas. All of the chapters can provide guidelines for spont psychologists who wish to be more inclusive, empowering, and effective in their research and practice. In the afterword, Johnson and Worell (1997) list common themes. Feminist practice

- Includes therapy/intervention, teaching, political action, consultation, writing, scholarship, research, supervision, assessment and diagnosis, administration, and public service

- Promotes transformation and social change

- Assumes the personal is political

- Embraces diversity as a requirement and foundation for practice

- Includes an analysis of power and the multiple ways in which people can be oppressed and oppressing

- Promotes empowerment and the individual woman's voice

- Promotes collaboration

- Promotes the value of diverse methodologies

- Promotes femigist consciousness

- Promoles self-reflection on a personal, discipline, and other levels as a lifelong process 
- Promotes continued evaluation and reflection of our values, ethics, and process, which is an active and reflective feminist process

- Asserts that misogyny and other inequities are damaging

- Encourages demystification of theory and practice

- Views theory and practice as evolving and emerging

The views of the feminist psychologists and the common themes reflect many of the calls for relational analyses and attention to power relations by the feminist sport studies scholars. But the psychologists also retain concern for the individual. Although the combined focus on the individual and social relations may seem paradoxical at furst glance, that combination is the essence of a useful feminist sport psychology. Our goal is to understand behavior and then to apply our understanding to help individuals in the real world. As we continue moving toward feminist sport psychology, we not only put our theories and research into action for individuals, but we can work for social change. We are just beginning our joumey. We will continue to move on to the greater challenge of shaping a feminist sport psychology that incorporates gender relations and values diversity in all areas of our professional practice.

\section{Overview of Contributions to This Special Issue}

The articles in this issue reflect many similar feminist themes and also present unique contributions to guide us toward feminist sport psychology. We clearly have an all-star line-up of authors to represent feminist sport psychology. Note that all of them would likely reject that "all-star" characterization as hierarchical and nonfeminist. Each author brings her unique perspective and special strengths to this issue. The merging of these contributions in this collaborative work illustrates the value of a diverse, dynamic feminist sport psychology.

First (and rightfully so), Carole Oglesby traces the roots and growth of feminist sport psychology. Carole is most qualified to write about our roots, and we likely would not have this issue without her early efforts. Carole's 1978 book offered the first feminist perspective on women and sport. Carole has consistently provided a feminist voice, and often the only feminist voice, in sport psychology. In true feminist leadership style, Carole has always given support and encouragement to "would-be" or "could-be" feminists. She rarely stands in the spotlight and quickly turns the light on larger issues, turaing feminist theory into feminist practice.

Ruth Hall has been drawn into sport psychology from her clinical psychology practice through collaborations with Carole as well as her own interests and commitment. Ruth's article highlights strength through diversity. Feminist sport psychology is more relevant, real, and richer as we include diverse views, particularly perspectives from women of color. Ruth has been calling for richer colors in our sport psychology perspective for some time. Her article may bring more of us into this effort as she reinforces the sport studies calls for relational analyses and recognition of multiple power relations.

Similarly, Vikki Krane underscores the call for relational perspectives and intersecting identities in her presentation of queer theory in relation to feminist sport psychology. Sexuality and sexual orientation are closely linked to gender 
relations and necessarily become part of feminist sport psychology. Vikki has contributed theoretical and empirical work on lesbians in sport to our literature. With this article, she brings that work into our ferminist sport psychology journey.

Brenda Bredemeier's paper reflects the influence of feminist sport studies scholars and ilustrates Ann Hall's call for feminist research and praxis. At one of our early AAASP conferences, Brenda and her (then) graduate students (all now feminist professionals) presented a feminist sport psychology symposium. They focused on women's sport experiences using alternative methods and listening to the women's voices long before qualitative methods were accepted in sport psychology. Brenda's continuing work on moral development continues to reflect praxis, and ber article highlights that feminist research-into-action approach.

Diane Whaley contributes a feminist sport psychology perspective on our methods. Although it has become common to equate feminist methods with qualitative methods. Diane presents a more inclusive view (and that seerns feminist to me). Diane calls for a variety of feminist methods as we find methods that fit our questions. Also, I appreciate Diane's inclusive view of sport- encompassing varied sport and exercise activities that reflect the role of physical activity in the lives of women of all ages and abilities.

The contributions of the young professionals (Christy Greenleat, Karen Collins, Tamar Semerjian, Jennifer Waldron, and Emily Roper) reinforce and confirm the themes of feminist sport psychology: valuing women and women's experiences; recognizing the intersecting power relations of gender, race, class, sexuality: and moving from theory to action and social change. The young professionals clearly incorporate views of the senior authors and feminist scholarship, but they provide their unique interpretations and insights ats they set new directions. Most of all, the young professionals show us that we are continuing to move in new directions on our feminist sport psychology journey.

\section{References}

Basow, S.A., \& Rubin, L.R. (1999). Gender influences and adolescent development. In N.G. Johnson, M.C. Roberts, \& J. Worell (Eds.), Beyond appearance: A new' look at adolescent girls (pp. 25-52). Washington. DC: American Psychological Association.

Gill. D.L. (in press). Gender and spon behavior. In T.S. Horn (Ed.), Advances in sport psuchology (2 ${ }^{\text {nd }}$ ed.). Champaign, IL: Human Kiaetics.

Hall. M.A. (1996). Feminism and sporting bodies. Champaign, IL: Human Kinetics.

looks, b. (1984). Feminist theory: From margin to center. Boston: South End Press.

hooks, b. (2000). Feminism is for everybody: Passionale polirics. Cambridge. MA: South End Press.

Johnson, N.G., \& Worell. J. (1997). Afterword. In J. Worell \& N.G. Johnson (Eds), Shaping the future of feminist psycholog. (pp. 245-249). Washington, DC: American Psychological Association.

Messner, M.A. (1992). Power at play: Sports and the problem of masculinity. Boston: Beacon Press.

National Amateur Athletic Federation. Women's Division (1930). Women and athlenics. New York: A.S. Bames.

Oglesby. C.A. (1978). Women and sport: From myth to reality. Philadelphia: Lea \& Febiger. 
Sherif, C.W. (1982). Needed concepts in the study of gender identity. Psychology of Wornen Quarterly, 6, 375-398.

Smith, Y.R. (1992). Women of color in sociery and sporr. Quest, 44, 228-250.

Trickett, E.J., Watts, R.J., \& Birman, D. (Eds.). (1994). Human diversity: Perspectives on people in context. San Francisco: Jossey-Bass.

Worell, J., \& Johnson, N.G. (Eds.). (1997). Shaping the future of feminist p.sychology. Washington. DC: Aunerican Psychological Association.

Worell, J., \& Remer, P. (1992). Feminist perspectives in therapy: An empowerment model for women. Chichester: Wiley.

Manuscript submitled: February 28. 2001

Revision received: July 10, 2001 